University of Michigan Law School University of Michigan Law School Scholarship Repository

2008

\title{
Third-Party Tax Administration: The Case of Low- and Moderate-Income Households
}

Michael S. Barr

University of Michigan Law School, msbarr@umich.edu

Jane K. Dokko

Board of Governors of the Federal Research System

Available at: https://repository.law.umich.edu/articles/1491

Follow this and additional works at: https://repository.law.umich.edu/articles

Part of the Banking and Finance Law Commons, Law and Society Commons, Taxation-Federal Commons, and the Tax Law Commons

\section{Recommended Citation}

Barr, Michael S. "Third-Party Tax Administration: The Case of Low- and Moderate-Income Households." J. K. Dokko, co-author. J. Empirical Legal Stud. 5, no. 4 (2008): 963-81.

This Article is brought to you for free and open access by the Faculty Scholarship at University of Michigan Law School Scholarship Repository. It has been accepted for inclusion in Articles by an authorized administrator of University of Michigan Law School Scholarship Repository. For more information, please contact mlaw.repository@umich.edu. 


\title{
Third-Party Tax Administration: The Case of Low- and Moderate-Income Households
}

\author{
Michael S. Barr and Jane K. Dokko*
}

\begin{abstract}
Using a unique household-level data set, this article investigates the taxfiling experiences and refund behavior of low- and moderate-income (LMI) households. We document households' tax-filing behavior, attitudes about the withholding system, use of tax refunds to consume and save, and the mechanisms by which households would prefer to receive their income. We also document the prevalence of the use of tax-preparation services and the receipt of tax refunds and refund-anticipation loans. Finally, we argue that there may be a role for tax administration to enable LMI households to make welfare-improving financial decisions.
\end{abstract}

\section{INTRODUCTION}

The U.S. federal income tax code has an enormous potential to shape the economic and financial decisions of tax-paying households. Tax rates, com-

*Address correspondence to Michael S. Barr, Professor of Law, University of Michigan Law School, 625 S. State St., Ann Arbor, MI 48109; email: msbarr@umich.edu. Dokko is Economist, Board of Governors of the Federal Reserve System.

Earlier versions of this article using preliminary and incomplete data were presented at the National Tax Association's 2005 Annual Conference on Taxation and the 2006 IRS Research Conference. This version of the article uses the final data set and is adapted from these working papers: Barr and Dokko (2006a, 2006b). The views expressed in this article are those of the authors and do not reflect those of the Federal Reserve Board or its staff. The authors thank their project manager, Esther Ullman, their production manager, Sara Freeland, Terry Adams, the Survey Research Center, and their Advisory Board. The article has received valuable comments from seminar participants at the University of Michigan, conference participants at the National Tax Association Annual Conference on Taxation, the IRS Research Conference, and an anonymous referee. The authors are grateful to Chester Choi, Maria Dooner, and Robyn Konkel for research assistance. The study received generous support from the Ford Foundation, Fannie Mae Foundation, Mott Foundation, MacArthur Foundation, Annie E. Casey Foundation, and Community Foundation of Southeastern Michigan, as well as from the National Poverty Center, Center on Local, State and Urban Policy, Provost, Vice President for Research, and Law School of the University of Michigan.

(C) 2008, Copyright the Authors

Journal compilation @ 2008, Cornell Law School and Wiley Periodicals, Inc. 
pliance laws, and the withholding system all create incentives, as do the methods by which the U.S. Treasury collects tax receipts and disburses tax refunds. The role of third-party service providers in the tax system is less well understood, even though tax-preparation firms have a prominent role in the U.S. tax system. Nationally, more than half of taxpayers use paid preparers to submit their tax returns. Low- and moderate-income households are among those who use the paid tax-preparation system. In fact, among those who file, more than two-thirds of low-income households use paid tax-preparation services. Thus, understanding the role of third-party providers in the tax system is critical to understanding how our tax system affects low-income households.

Tax-preparation service providers can potentially both help and hurt taxpayers. On the positive side, tax-preparation firms may increase the likelihood that taxpayers will hear about and take advantage of tax incentives designed to reach them. For example, over 20 million low- and moderateincome households file for approximately $\$ 35$ billion in refunds and reduced tax liability under the Earned Income Tax Credit (EITC), designed to reward work for low-income working families. On the negative side, tax-preparation firms can add to the efficiency costs of the tax system and reduce the amount of redistribution through the EITC and other tax credits and expenditures. Furthermore, tax preparation is a high-fee service in itself, and low-income households often face additional, ancillary fees associated with filing. For example, many low-income households lack bank accounts and may also pay a nontrivial fee to cash their government refund check at a check casher or other establishment. A large portion of households receiving the EITC, in addition, take out costly refundanticipation loans and similar products in order to receive the proceeds of their tax refund more quickly or to pay for tax services (Berube et al. 2002). Understanding the institutional context in which tax refund distribution occurs, including households' attitudes toward the withholding system, is important for understanding the efficiency and distributional aspects of the tax system.

In this article, using data from the Detroit Area Household Financial Services (DAHFS) study, a unique household survey that we designed and implemented in the field with the Survey Research Center at the University of Michigan, we examine the tax-filing experiences of LMI households. We document households' current tax-filing behavior, their attitudes about the withholding system, their use of tax refunds to consume and save, and the mechanisms by which they would like to receive their refunds. Overall, there 
is little empirical evidence on the tax-filing experiences of LMI households. Toward this end, we document the prevalence of the use of tax-preparation services and the receipt of both tax refunds and refund-anticipation loans (RALs). We describe the reasons taxpayers cite for taking out RALs and the uses to which they put their tax refunds. Finally, based on individuals' responses to a hypothetical scenario in which individuals choose the time profile of how they pay their taxes and receive their refunds, we also begin to explore the extent to which households use the withholding system as a financial planning tool.

Based on this information, in the conclusion, we suggest policy implications for tax administration and saving policies. The evidence on LMI households' tax-filing experiences informs the policy debate over tax complexity (Holtzblatt \& McCubbin 2004; Barr 2004; President's Advisory Panel on Federal Tax Reform 2005). In addition, the conclusion begins to assess whether households' use of paid tax preparers reflects decisions made by self-interested agents. We also discuss whether default rules, framing, and heuristics play a role in LMI households' tax-filing behaviors (Thaler 1990).

The remainder of this article is organized as follows. The next section presents the policy context and previous research on tax-filing behavior among LMI households. The third section describes the survey, sampling plan, and data. Following this section, we present our results. We conclude with policy implications and further research questions.

\section{Policy Context and Previous Research}

Paid tax preparers provide valuable services to taxpayers but charge high fees, leaving the net benefits ambiguous. On behalf of households facing conflicting and complex rules under different tax provisions for determining household status and dependents, tax preparers interface with the Tax Code. Furthermore, they also serve households who worry about increased IRS audits (particularly among EITC filers) and IRS delays in receiving their refunds (Holtzblatt \& McCubbin 2004). Tax preparers may also expand the take-up rate for the EITC and other tax credits designed to redistribute income to households through advertising the availability of refunds and expertise in filing returns to maximize the client's use of available tax credits (Kopczuk \& Pop-Eleches 2005). Commercial tax preparers also can serve as a vehicle through which to encourage savings, including retirement savings (Barr 2004; Duflo et al. 2005). 
On the other hand, commercial tax preparers charge high fees and the use of refund-anticipation loans (RALs) imposes additional fees. In addition to RALs, tax preparers offer other high-fee financial services, such as loans to pay taxes owed or prepaid debit cards with complex fee structures. Unbanked households often must pay a third party, often the tax preparer, to convert their refund checks into a fungible medium. Finally, paid tax preparers may reduce the salience of an administratively complicated tax system, thereby reducing the urgency of the need for tax reform (Friedman \& Friedman 1998; Finkelstein 2007).

Many tax filers use paid tax preparers in order to receive their tax refunds due to having overwithheld their income and having prepaid the IRS an amount greater than the taxes (less any credits) owed at the end of the year. ${ }^{1}$ Overwithholding occurs at many income levels, and is a common phenomenon among LMI taxpayers. Given their low incomes, overwithholding by such taxpayers is puzzling. By overwithholding, households, in effect, deny themselves access to their take-home pay until they receive a lump-sum tax refund.

A number of factors may influence this pattern of overwithholding among LMI households. First, it may be difficult for such households to adjust their withholding payments to match their income tax liability. Very few households use the advanced Earned Income Tax Credit, through which a large portion of their anticipated tax refund could be moved earlier to increase regular take-home pay. The structure of the EITC and its advanced counterpart may be too complicated; employees may be reluctant to ask their employers to implement the provision; and employers may be reluctant to adjust their withholding (or ignorant of how to do so). Moreover, complicated employment patterns over the year, with multiple jobs, may make adjusting withholding difficult.

Second, uncertainty about tax liability may deter income smoothing through the withholding system. Taxpayers may fear that adjusting withholding would result in an underpayment of taxes, with significant sums owed (perhaps with penalties) at the end of the tax year. For low-income households, the risk of underwithholding resulting in lump-sum tax liability may be too great. Also, some households may dislike the act of submitting a

\footnotetext{
${ }^{1}$ In the United States, the IRS collects taxes on earned income by requiring employers to remit a portion of the employees' paychecks as a prepayment of the taxes owed at the end of the year. If the amount prepaid is greater than the taxes owed, then the employee has overwithheld and is entitled to a tax refund in the amount of the difference.
} 
payment to the IRS (or may encounter administrative difficulties if they do not have a bank account). In addition, the complexity of eligibility rules for the EITC and other tax credits, particularly as such rules relate to family structure, may increase the uncertainty involved in determining the appropriate amount of withholding.

Third, taxpayers may like the nonsmooth timing of how they receive their income, the lump-sum nature of tax refunds, and their default withholding patterns. In many contexts, individuals prefer rising (or nonsmooth) income and consumption profiles (holding the present value of these profiles constant) (see Thaler \& Loewenstein 1989). Individuals may also use "mental accounts" to finance large purchases using income received as a lump sum (Thaler \& Loewenstein 1989; Thaler 1990). Given a bias for the status quo, individuals may find deviating from the default withholding pattern (corresponding to crudely filling out a W-4 form) both difficult and unpleasant. Based on the services offered by the leading tax-preparation firms, tax preparers are keenly aware of LMI individuals' potential motives for overwithholding. An understanding of these motives informs how the tax-filing experience interacts with households' consumption and saving decisions (Shapiro \& Slemrod 1995; Souleles 1999).

Regardless of whether households intentionally overwithhold, respond to uncertainty, or simply adhere to the tax system's default rules (because of inertia), LMI households do in effect use the institutional features of the withholding system to save in the short term (i.e., for a period of less than one year). There is a consensus that the poor have few assets and find it difficult to save out of current income (for a summary, see Barr 2004). In light of high-fee financial and banking services, as well as barriers to saving facing LMI households, the withholding system may provide a mechanism for saving. ${ }^{2}$ Furthermore, their attitudes about the withholding system may reflect an awareness that they are able to save by overwithholding and subsequently receive a sizeable (lump-sum) tax refund. Research has noted the importance of mental accounts in influencing households' marginal propensities to consume (MPC) income, with a smaller MPC the larger the tax refund (Thaler \& Loewenstein 1989; Thaler 1990; Souleles 1999). As a large lump-sum payment, the EITC and related tax refunds could present a saving opportunity for LMI households that they may not otherwise have

\footnotetext{
${ }^{2}$ See Barr (2004), Duflo (2004), and Bertrand et al. (2005) for further discussion of these constraints and their contributions to poverty and other socioeconomic conditions.
} 
(Souleles 1999; Barr 2004; Tufano et al. 2005; Duflo et al. 2005; Rhine 2005). As we describe in more detail below, we document LMI households' withholding preferences in order to investigate the evidence for believing that households want to use the withholding system to save.

\section{Description of Survey, Sampling, And Data}

The data for this article are from the Detroit Area Household Financial Services (DAHFS) study, a survey we designed and implemented with the Survey Research Center (SRC) at the University of Michigan. The survey focuses on LMI individuals' experiences with formal and informal financial institutions, including their tax-filing experiences, in addition to their socioeconomic characteristics. ${ }^{3}$ The final survey was programmed for computerassisted, in-person interviewing. The final survey instrument is, on average, 76 minutes in length.

The sample members were selected based on a stratified random sample of the Detroit metropolitan area (Wayne, Oakland, and Macomb Counties). We drew sample members from Census tracts with median incomes that are 0-60 percent (low), 61-80 percent (moderate), and 81-120 percent (middle) of the Detroit area's median income of $\$ 49,057$. Because we oversampled low- and moderate-income strata and undersampled the middle-income one, sample members are more likely to be drawn from the low- and moderate-income strata. Stratum definitions do not, however, restrict the income levels of the sample members to fall within these ranges. ${ }^{4}$ Upon selecting a household, SRC randomly selected an adult to interview from that household (Kish 1949). The DAHFS study generalizes to both the adult individuals and households living in Census tracts with median incomes less than 120 percent of the Detroit area's median, and is therefore not representative of the U.S. population.

The data set consists of individuals who completed the interview between July 2005 and March 2006, with over 90 percent of the interviews

\footnotetext{
${ }^{3}$ Because there is no such comprehensive survey about the financial services experiences and attitudes of low- and moderate-income households, the questionnaire required extensive development, pretesting, and validation.

${ }^{4}$ With sampling weights, the sample represents the population of Detroit metropolitan area residents living in low-, moderate-, and middle-income Census tracts.
} 
occurring before January 2006. We attained a 65 percent response rate and interviewed over 1,000 households. Upon completion of the data collection, SRC constructed sampling weights that are inversely proportional to an individual's probability of selection. ${ }^{5}$ All estimates in this article are weighted and all standard errors are "clustered" at the segment (Census-tract) level to account for the intrasegment correlation across individuals.

The sample studied in this article consists of 938 respondents from the low- and moderate-income strata. Because there were few economically and statistically meaningful differences between these two strata, the results are based on this combined sample of 938 respondents. ${ }^{6}$ Of these respondents, 73 percent report they filed a tax return in 2004 or $2003 .^{7}$ As seen in Table 1, many in this sample of LMI tax filers belong to socially disadvantaged groups. Sixty-nine percent self-identify as black or African American, and 30 percent have less education than a high school degree. Around two-thirds of the sample is female, which reflects that singlefemale-headed households are more common than single-male-headed households in the LMI neighborhoods of the Detroit metropolitan area. Table 1 also compares the DAHFS sample to the U.S. Census characteristics of the households from the low- and moderate-income Census tracts in the Detroit metropolitan area. In terms of age and race, the DAHFS sample matches well the Census data. For sex, education, and marital status distributions, the DAHFS sample differs somewhat from the Census data but in ways consistent with the sampling design, which is sensitive to the greater presence of single-female-headed households (who, on average, are less likely to be married and more likely to obtain postsecondary education).

\footnotetext{
${ }^{5}$ Details on the construction of sampling weights are available from the authors on request.

${ }^{6}$ The disaggregated results are available on request.

${ }^{7}$ In the survey, if respondents did not file a tax return in 2004, we asked about their tax-filing experiences in 2003. If someone is a financially uninvolved spouse or a dependent, it is possible that he or she responded "no" to the question of whether he or she filed a tax return even though his or her household may have filed one. We opted to ask the respondent about his or her own tax experiences, as opposed to the household's experiences because of data-quality concerns. Respondents who did not file a return would probably not be able to recall survey items, such as whether the household filed for the EITC or the size of their tax refund.
} 
Table 1: Characteristics of Survey Sample by Banked Status (Standard Errors in Parentheses)

\begin{tabular}{lcccc}
\hline Characteristic & $\begin{array}{c}\text { Detroit } \\
\text { Metrot }\end{array}$ & All & Banked & Unbanked \\
\hline Black & $71 \%$ & $69 \%$ & $68 \%$ & $78 \%$ \\
White & 22 & 20 & 19 & 14 \\
Arab & NA & 2 & 3 & 1 \\
Other & 8 & 9 & 10 & 7 \\
Female & $52 \%$ & $66 \%$ & $67 \%$ & $66 \%$ \\
Less than HS diploma & $36 \%$ & $30 \%$ & $27 \%$ & $37 \%$ \\
HS diploma or GED & 31 & 23 & 19 & 33 \\
Greater than HS diploma & 33 & 47 & 54 & 30 \\
Age & 44 & $43(1.0)$ & $45(1.1)$ & $40(1.2)$ \\
Born in the U.S. & $93 \%$ & $92 \%$ & $90 \%$ & $96 \%$ \\
Single/never married & $44 \%$ & $46 \%$ & $38 \%$ & $65 \%$ \\
Married and living with spouse & 25 & 20 & 24 & 9 \\
Living with partner & NA & 4 & 4 & 5 \\
Separated/widowed/divorced & 31 & 30 & 34 & 21 \\
Household has no children & NA & $67 \%$ & $71 \%$ & $59 \%$ \\
Employed at interview & $45 \%$ & $54 \%$ & $59 \%$ & $42 \%$ \\
Not in labor force at interview & 47 & 17 & 16 & 18 \\
Unemployed at interview & 8 & 29 & 24 & 40 \\
Participates often in financial & NA & $75 \%$ & $78 \%$ & $66 \%$ \\
$\quad$ decisions & & & & \\
Total HH monthly income & NA & $2,248(334)$ & $2,703(439)$ & $1,156(399)$ \\
Annual HH income in 2004 & NA & $28,435(2,118)$ & $33,224(2,573)$ & $17,078(1,467)$ \\
Median HH income in 2004 & 24,146 & 20,000 & 25,000 & 10,000 \\
\% below the poverty line & $32 \%$ & $33 \%$ & $26 \%$ & $50 \%$ \\
Sample size & - & 938 & 668 & 270 \\
\hline
\end{tabular}

+ Statistics for the Detroit metropolitan area (Wayne, Oakland, and Macomb Counties) are obtained from the U.S. Census's FactFinder. To facilitate comparison with the DAHFS study, the Census statistics are obtained from Census-tract-level summary data for tracts with median incomes under 80 percent of the tri-county median of $\$ 49,051$.

NoTEs: Not in labor force includes respondents who said they were retired, homemakers, students, did not have the required documentation, or chose not to work. Nonemployed is the percentage of people currently unemployed who are in the labor market. Poverty guidelines come from the Department of Health and Human Services, obtained from http:// aspe.hhs.gov/poverty/04poverty.shtml. Respondents are banked if they responded yes to having a checking account, a savings account, an account with a debit card but no checks, or any other account held at a bank, savings and loan, or credit union. Unbanked respondents responded no to having any of these types of accounts.

Source: Detroit Area Household Financial Services Study.

In this article, we present results from the tax module of the survey, which consists of 21 questions, some with multiple parts. These questions pertain to experiences the respondents had in filing their taxes. This means that we do not necessarily capture all the experiences of the household. The 
question asked to tax filers concerning their withholding preferences reads as follows. ${ }^{8}$

Next we have a question about how people think about tax refunds. In this question, you have a choice of how you get your income. The total amount of your tax refund or money owed will be the same for each option. But you can choose whether you get the money spread out over the year or all at the end. I will read the question and your answer choices-you can read along from this page.... For this question, please assume that you receive a regular paycheck from an employer. Which of the following describes how you would like to receive your income?

A paycheck that is $\$ 100$ smaller each month than your current one with a tax refund that is $\$ 1200$ larger at the end of the year;

A paycheck that is the same as your current one with no additional refund and no need to pay any additional taxes at the end of the year;

A paycheck that is $\$ 100$ larger each month than your current one with a tax refund that is $\$ 1200$ smaller at the end of the year.

If the respondent chose the third option, we proceeded with the following followup to ascertain whether framing the question in terms of a tax refund differs from the respondent having to owe a tax liability.

Would you want a paycheck that is $\$ 100$ larger each month than your current one if you owed $\$ 1200$ more in taxes at the end of the year?

\section{Results}

Table 2 documents the tax-filing experiences of our sample. Although about 73 percent of the sample filed a tax return in the last two years, the tax-filing experiences of our respondents reflect their socioeconomic disadvantages. About 82 percent of tax filers received a refund, and the average refund size was a little over $\$ 2,000$ among those receiving a refund. Approximately 41 percent of tax filers were aware that they had applied for the EITC, and 33 percent of them reported receiving it (we expect that others were simply not aware of the specific provisions connected to the filing of their tax return).

\footnotetext{
${ }^{8} \mathrm{~A}$ respondent is a tax filer if he or she filed a tax return in 2004 or 2003.
} 
Table 2: Average Tax-Filing Experiences of Banked, Unbanked, EITC Filers, and Nonfilers (Standard Errors in Parentheses)

\begin{tabular}{|c|c|c|c|}
\hline Characteristic & All & Banked & Unbanked \\
\hline Filed a tax return in 2003 or 2004 & $73 \%$ & $79 \%$ & $57 \%$ \\
\hline Received a refund ${ }^{a}$ & $82 \%$ & $81 \%$ & $84 \%$ \\
\hline Amount of federal refund & $2,078(102)$ & $2,100(135)$ & $2,004(144)$ \\
\hline Filed for EITC & $41 \%$ & $38 \%$ & $51 \%$ \\
\hline Received EITC & $33 \%$ & $30 \%$ & $43 \%$ \\
\hline Used paid tax preparer & $66 \%$ & $66 \%$ & $67 \%$ \\
\hline Filed by mail & 10 & 11 & 7 \\
\hline Filed by computer/phone & 8 & 9 & 3 \\
\hline Used free service to file & 4 & 3 & 8 \\
\hline Got help from a friend & 5 & 4 & 9 \\
\hline Other & 7 & 7 & 6 \\
\hline \multicolumn{4}{|l|}{ Type of paid tax preparer used ${ }^{\mathrm{b}}$} \\
\hline National chain & $45 \%$ & $40 \%$ & $60 \%$ \\
\hline Local firm & 22 & 24 & 17 \\
\hline Accounting firm & 17 & 19 & 11 \\
\hline Other & 16 & 17 & 12 \\
\hline Received $\mathrm{RAL}^{\mathrm{c}}$ & $38 \%$ & $30 \%$ & $65 \%$ \\
\hline Cost of tax preparation ${ }^{\mathrm{d}}$ with RAL & $177(10)$ & $171(12)$ & $187(15)$ \\
\hline Cost of tax preparation ${ }^{e}$ & $112(7)$ & $115(8)$ & $93(18)$ \\
\hline Sample size & 938 & 668 & 270 \\
\hline
\end{tabular}

aPercentages are based on those who have filed a tax return.

${ }^{\text {b}}$ Percentages are based on the sample of respondents using paid tax preparers.

'Percentages are based on respondents using a paid tax preparer to file taxes in 2003 or 2004. ${ }^{\mathrm{d}}$ Averages are computed for respondents who took out a RAL.

EAverages are computed for respondents using a paid tax preparer but not taking out a RAL. Source: Detroit Area Household Financial Service Study.

The DAHFS study confirms national results that find a large portion of LMI taxpayers use paid preparers. ${ }^{9}$ In the DAHFS study, 66 percent of lowand moderate-income tax filers used a paid preparer to file their returns. About 38 percent of taxpayers using a paid preparer took out a RAL or "fast refund" product, which translates to 25 percent of all tax filers or 37 percent of all taxpayers receiving a tax refund. Tax-preparation services are costly relative to income and refund size among this sample of LMI respondents.

\footnotetext{
${ }^{9}$ According to IRS data (on file with the authors), in TY2003, in Macomb, Oakland, and Wayne Counties, 59.8 percent of all tax filers used a paid preparer; 10.6 percent of all tax filers received a RAL; 17.7 percent of all tax filers who pay received a RAL; 72.3 percent of EITC filers pay for preparation services; 38.0 percent of EITC filers received a RAL; and 52.5 percent of EITC filers who pay received a $\mathrm{RAL}$.
} 
On average, RAL users of paid preparers paid $\$ 177$ for tax preparation and RAL services, which represents 8 percent of the average refund of such households $(\$ 2,105)$. Among non-RAL users of paid preparers, the cost of tax preparation alone is $\$ 110$, which represents 7 percent of the average refund of these households $(\$ 1,595) .{ }^{10}$

Banked and unbanked individuals have different tax-filing experiences, even though, conditional on filing, banked and unbanked households are equally likely to receive a tax refund. Banked households are 13 percentage points less likely to file for and receive the EITC than unbanked households. Though paid tax-preparation services are nearly equally likely to be used by both banked and unbanked individuals, the latter group is about 20 percentage points more likely to use a national chain, like $H \& R$ Block or Jackson Hewitt, rather than a local firm or accountant, to file their taxes. Moreover, unbanked households are twice as likely to take out a RAL. More than 60 percent of unbanked households using a paid preparer took out a RAL, compared with 30 percent of banked households using paid preparers. These differences persist when controlling for income and employment (results not shown). These results are consistent with the notion that unbanked households are influenced in their decision to take out a RAL because they need to wait much longer than banked households to receive their refund. Typically, the IRS disburses refund checks by mail in four to six weeks of filing one's taxes, which is about one month longer than for banked households filing electronically and using direct deposit. Still, unbanked households make up only 38 percent of RAL users as a whole, suggesting that banked households also use RALs in significant numbers.

Table 3 lists reasons that individuals cite for taking out RALs. About 90 percent of RAL recipients state they did so because they wanted the money faster, and most of these correlate highly with the nearly 80 percent of households who said they took out a RAL because they want to pay their bills or other debt faster. That is, they borrowed to pay down other debt. Although the APR of a RAL is an order of magnitude higher than the interest rates for most (if not all) types of consumer credit, RAL takers may

\footnotetext{
${ }^{10}$ During survey development, respondents were not able to distinguish separately the amount that they paid to tax preparers for tax preparation as distinct from the cost of RALs so the final questionnaire asks about combined costs. We report the total cost for tax preparation and RALs, and will later impute separate costs.
} 
Table 3: Reasons for Obtaining an RAL by Banked Status

\begin{tabular}{llll}
\hline Characteristic & All & Banked & Unbanked \\
\hline Wanted refund sooner & & & \\
$\quad$ Very important & $55 \%$ & $54 \%$ & $56 \%$ \\
$\quad$ Somewhat important & 33 & 30 & 37 \\
$\quad$ Not at all important & 13 & 16 & 7 \\
Needed to pay tax preparer & & & \\
$\quad$ Very important & $16 \%$ & $14 \%$ & $19 \%$ \\
$\quad$ Somewhat important & 31 & 28 & 35 \\
$\quad$ Not at all important & 53 & 58 & 46 \\
Wanted to pay bills faster & & & \\
$\quad$ Very important & $60 \%$ & $51 \%$ & $73 \%$ \\
$\quad$ Somewhat important & 17 & 18 & 17 \\
$\quad$ Not at all important & 23 & 31 & 11 \\
Wanted to be sure about getting & & & \\
$\quad$ the refund & & & \\
$\quad$ Very important & $32 \%$ & $27 \%$ & $39 \%$ \\
$\quad$ Somewhat important & 24 & 28 & 18 \\
$\quad$ Not at all important & 44 & 45 & 43 \\
Other reason & $11 \%$ & $10 \%$ & $13 \%$ \\
Sample size & 156 & 95 & 61 \\
- & & & \\
Conditional on receiving a refund & & & \\
\hline
\end{tabular}

${ }^{a}$ Conditional on receiving a refund-anticipation loan (RAL). NoTEs: Respondents are banked if they responded yes to having a checking account, a savings account, an account with a debit card but no checks, or any other account held at a bank, savings and loan, or credit union. Unbanked respondents responded no to having any of these types of accounts.

Source: Detroit Area Household Financial Service Study.

face other costs on outstanding debt (such as late fees). ${ }^{11}$ These other costs would have to be quite high, however, to justify taking out a RAL to pay down outstanding debt. Interestingly, to the extent that these individuals are paying down debt, they are in effect borrowing money in order to increase net savings. In addition, some 56 percent of households take out a RAL because they want certainty about getting their refund. Nearly half of respondents reported that an important reason for taking out a RAL is simply to pay the tax preparer for tax-preparation and filing services. That is, low incomes and liquidity constraints may prevent taxpayers from paying to file in order

\footnotetext{
${ }^{11}$ For a historical overview of consumer credit interest rates, see the Federal Reserve Board's G.19 statistical release. Calculations of the dollar-weighted average interest rate on all outstanding nonmortgage debt are available from the authors on request.
} 
to receive their large, lump-sum refunds, absent taking out an expensive RAL.

Individuals without a bank account are somewhat more likely to want the money faster than those with bank accounts. Moreover, unbanked households are 21 percentage points more likely than banked households to state that they used a RAL because they wanted to pay bills or debt faster. This differential potentially reflects the differences in timing of receipt of refund by direct deposit as compared to paper check, as well as other differences other than banked status, including income and asset holdings, which will require further investigation. Unbanked households are also 12 percentage points more likely to take out a RAL in order to pay the tax preparer, than are banked households.

Table 4 presents results on how low- and moderate-income households use their refunds. For policy purposes, it is important to assess whether there is a propensity among low-and moderate-income households to save some or all of their refunds. Tax refunds, given the size of the lump sum relative to annual income, may play an important role in most low- and moderateincome households' lives. About 84 percent of tax filers, and 60 percent of the DAHFS study's sample of low- and moderate-income households, received a tax refund, and the average refund of those receiving one was $\$ 2,078$. More

Table 4: Use of Tax Refund by Banked Status and Receipt of RAL

\begin{tabular}{|c|c|c|c|c|c|}
\hline Characteristic & All & Banked & Unbanked & Received RAL & No RAL \\
\hline Received a refund & $84 \%$ & $83 \%$ & $87 \%$ & $95 \%$ & $80 \%$ \\
\hline Saved all of refund ${ }^{a}$ & $10 \%$ & $11 \%$ & $5 \%$ & $5 \%$ & $12 \%$ \\
\hline Spent all of refund & 50 & 47 & 60 & 56 & 47 \\
\hline Saved some/spent some & 41 & 42 & 35 & 39 & 41 \\
\hline \multicolumn{6}{|l|}{ Spent refund on ${ }^{b}$} \\
\hline Bills or other debt & $79 \%$ & $78 \%$ & $82 \%$ & $82 \%$ & $77 \%$ \\
\hline Buy appliances & 20 & 16 & 32 & 23 & 18 \\
\hline Buy car & 12 & 10 & 17 & 19 & 9 \\
\hline Pay for education ${ }^{c}$ & 14 & 14 & 13 & 14 & 14 \\
\hline Other & 39 & 42 & 31 & 41 & 38 \\
\hline Sample size & 938 & 668 & 270 & 159 & 313 \\
\hline
\end{tabular}

${ }^{2}$ Conditional on receiving a refund.

"Conditional on "spending all" or "spending some and saving some" of the tax refund.

'Either the respondent's or the household's children's education.

NoTEs: Respondents are banked if they responded yes to having a checking account, a savings account, an account with a debit card but no checks, or any other account held at a bank, savings and loan, or credit union. Unbanked respondents responded no to having any of these types of accounts.

Source: Detroit Area Household Financial Services Study. 
than 50 percent of low-and moderate-income individuals who received a tax refund indicated that they saved all ( 10 percent) or a part ( 41 percent) of their tax refunds. Almost half of those receiving tax refunds spent the entirety of their refunds. Among those who spent some or all of their refund (90 percent), nearly 80 percent used their refund to pay down bills or other debt. That is, even among the group that spent some or all of their refund, most households indicated that they used the spending to increase net savings by reducing indebtedness (for related work, see Shapiro \& Slemrod 1995).

The lump-sum nature of tax refunds may also make it useful for large asset purchases in the face of liquidity constraints or difficulties constraining consumption to save up for such purchases. About 20 percent of respondents used their refund to buy appliances and another 12 percent used the refund to buy a car. Another 14 percent of respondents used the refund to pay for their own education or their children's education, an important investment in human capital.

The propensity to save some or all of their tax refunds is high among both banked and unbanked individuals. Although unbanked households are only half as likely to save all of their tax refund, 40 percent of unbanked households saved at least some of their refund, not too far behind the 53 percent rate for banked households. For both groups, the patterns of spending their refunds were roughly similar. That is, among those households who spent some or all of their refund, nearly 80 percent of both banked and unbanked households stated that they used their refund to pay down bills or other debt. Unbanked households were nearly twice as likely as banked households to say they spent their refund to buy appliances (32 percent compared to 16 percent). Saving plans tied to tax refunds may be a way for both types of household to save, especially given the difficulty these families have saving during the course of the year.

Table 4 also shows how households who do and do not receive RALs spend or save their tax refunds. RAL users are less than half as likely as non-RAL users to save the entirety of their refunds, but 5 percent of them still save all of it, and 44 percent of RAL users save some of their refund, quite close to the 53 percent of non-RAL takers who save some of their refund. RAL takers are nine percentage points more likely to spend all of their refunds than non-RAL users ( 56 percent compared with 47 percent). Among those who spent some or all of their refund, both RAL users and non-RAL users had similar spending patterns. About 80 percent of both groups spent some of their refund to pay down bills or other debt. RAL takers were 15 percentage points more likely to purchase a durable good, such as an appliance or a car. 
Table 5: Tax Receipt and Withholding Preferences of Low- and ModerateIncome Households by Banked Status

\begin{tabular}{lccc}
\hline & All & Banked & Unbanked \\
\hline Respondent would like*** & & & \\
$\quad$ More withheld \& bigger refund & $35 \%$ & $35 \%$ & $35 \%$ \\
Same withheld \& same refund & 46 & 48 & 42 \\
$\quad$ Less withheld \& smaller refund & 19 & 17 & 24 \\
Respondent would like less withheld \& more taxes*** & $6 \%$ & $5 \%$ & $10 \%$ \\
Respondent wants to overwithhold*** & $69 \%$ & $71 \%$ & $61 \%$ \\
Sample size & 938 & 668 & 270 \\
\hline
\end{tabular}

***See text for description and wording of the withholding question administered to tax filers. Respondents "want to overwithhold" if they state they want more overwithholding or want the same amount while receiving a refund.

Notes: Respondents are banked if they responded yes to having a checking account, a savings account, an account with a debit card but no checks, or any other account held at a bank, savings and loan, or credit union. Unbanked respondents responded no to having any of these types of accounts.

Source: Detroit Area Household Financial Survey Study.

Given few differences in the use of the refund between RAL takers and nontakers, however, it appears that the receipt of a RAL is not well correlated with how individuals spend the money. That is, households who wait for their tax refunds spend in similar ways from those who do not wait. A comparison of the interest rates on most forms of consumer credit and the average cost of a RAL suggests that the use of a RAL to pay down other debt is not economically justified for households holding traditional forms of credit.

The results in Table 5 suggest that nearly half of LMI taxpayers prefer their current withholding pattern, under which they mostly receive refunds. Holding total tax liability constant, another third would like to have more withheld, further reducing current income in order to receive a larger refund. A much smaller group, about 19 percent, would like less withheld in order to have higher current income. Consistent with behavioral insights about framing, this percentage drops to 6 percent if the respondents answer the question of whether they would like less withheld in order to have higher current income if it means that they would owe more in taxes at the end of the year, again, holding total tax liability constant.

LMI households' view of the withholding system is, for the most part, favorable. Overall, 69 percent of households want to overwithhold their income, meaning that they either want more overwithholding or want the same amount while receiving a refund. The banked are 10 percentage points more likely to want to overwithhold. LMI households' preferences for over- 
withholding in order to obtain a lump-sum refund, however, are somewhat at odds with the finding that the sample is, on average, socioeconomically disadvantaged, incurs debt during the year that is paid down with the tax refund, and feels financially insecure during the year (result not shown) ${ }^{12}$ Also (results not shown), households who want less withholding are more likely to experience food insufficiency (19 percent vs. 11 percent) and material hardship ( 37 percent vs. 28 percent), relative to those households who want the same or more withholding. Even among households who prefer the current withholding system, tax refunds are often applied to past debt. It may be the case that such households incur debt, knowing that they will be able to pay it back with their tax refund. It may also be possible that such households are aware that they lack self-control and would incur debt even if their incomes were smoother with less withholding; for these households, overwithholding, combined with credit constraints, may keep overall consumption lower.

The with holding system may make it difficult for some LMI households to smooth their consumption, but other households may use the withholding system for their financial planning. In the DAHFS study, weak evidence suggests that households may use the withholding system as a precommitment device against overconsumption. ${ }^{13}$ The withholding system may provide a low out-of-pocket fee way to save and build assets. ${ }^{14}$

\section{Conclusions and Policy Implications}

The key findings of this article are threefold. First, many low- and moderateincome households are connected to the tax system. Around 73 percent of the individuals in our sample filed a tax return, and 82 percent of those filing

\footnotetext{
${ }^{12}$ More specifically, roughly 72 percent of the sample finds it somewhat or very difficult to live on their total household income. During the year prior to the survey, over half the sample did not have sufficient income to meet their expenses every month.

${ }^{13}$ In particular, individuals who want more withholding are more likely to spend some or all of their refunds. They are also more likely to report they would like an option permitting them to receive part of their refund immediately and put part in a savings or investment fund (split refund).
}

\footnotetext{
${ }^{14}$ Relative to those who want less withholding, individuals who want more withholding are more likely to use their refunds to purchase a car (13 percent vs. 7 percent) or an appliance (24 percent vs. 15 percent). They are also less likely to hold a credit card ( 42 percent vs. 53 percent), and have fewer assets.
} 
received a tax refund. This finding suggests that the tax system is critical to the financial lives of low-income households and may serve as a vehicle to integrate low- and moderate-income households into the financial mainstream.

Second, many low- and moderate-income households use a paid preparer and take out RALs, often paying high fees. Given the societal goal of rewarding work and redistributing income to lower-income households, optimal income redistribution policy suggests that policymakers should focus on reducing the transaction costs associated with tax filing for low-and moderate-income households. Such steps could include measures to reduce tax complexity for low- and moderate-income filers (see, e.g., Holtzblatt \& McCubbin 2004; Barr 2004; President's Advisory Panel on Federal Tax Reform 2005). In addition, there are a series of measures that could be undertaken to bring low-income households into the banking system (Barr 2004). Banked households may face less compelling incentives to take out RALs because their refunds can be direct deposited more quickly than receiving a paper check, would likely face fewer liquidity constraints, and they would face lower costs for converting the income into usable form because they would not need to cash the government refund check. Thus, policy initiatives to bring low-income households into the banking system, such as a tax credit provided to financial institutions for providing low-cost, electronically-based bank accounts to low-income households, would likely contribute to optimal income redistribution policy (Barr 2004). In addition, Congress might consider authorizing the IRS to direct deposit tax refunds into privately offered new accounts for the unbanked (Barr 2007).

Third, the tax-filing process may provide an opportunity to encourage savings. Households in our study prefer to overwithhold. Our findings suggest that low- and moderate-income households may find savings plans that are tied to tax refunds (Duflo et al. 2005) attractive, particularly those plans that are not focused solely on retirement. Despite the fact that most households in our study have difficulty saving regularly during the course of the year, and hold few assets, many respondents save some or part of their refund, and those who spend it often use the refund to pay bills or other debt, thereby increasing net savings. A sizeable group of respondents also use the tax refund for lump-sum purchases, such as appliances and automobiles. This evidence suggests that individuals may view the withholding system as a means of short-term saving and as a precommitment device against overconsumption, although alternative explanations based on uncertainty regarding tax liability are highly plausible. 


\section{REFERENCES}

Barr, Michael S. (2004) "Banking the Poor," 21 Yale J. on Regulation 121.

(2007) "An Inclusive, Progressive National Savings and Financial Services Policy," 2007(1) Haruard Law Ẽ Policy Rev. 161.

Barr, Michael S., \& Jane K. Dokko (2006a) "Tax Preparation Services Among Lowand Moderate-Income Households," paper presented at the Proceedings of the 98th Annual National Tax Association Conference.

(2006b) "Tax Filing Experiences and Withholding Preferences of Low- and Moderate-Income Households: Preliminary Evidence from a New Survey," paper presented at the Proceedings of the 2006 IRS Annual Conference.

Bertrand, Marianne, Sendhil Mullainathan, \& Eldar Shafir (2005) "A BehavioralEconomics View of Poverty," 94 American Economic Rev. Papers $\mathcal{E}$ Proceedings 419.

Berube, Alan, Anne Kim, Benjamin Forman, \& Megan Burns (2002) The Price of Paying Taxes. Washington, DC: Brookings Urban Center and the Progressive Policy Institute.

Duflo, Esther (2004) "Poor But Rational?" in A. Banerjee, R. Benabou, \& D. Mookherjee, eds., What Have We Learnt About Poverty? Oxford: Oxford Univ. Press.

Duflo, Esther, William Gale, Jeffrey Liebman, Peter Orszag, \& Emmanuel Saez (2005) Saving Incentives for Low- and Middle-Income Families: Evidence from a Field Experiment with $H \mathcal{E}^{2} R$ Block. NBER Working Paper 11680.

Finkelstein, Amy (2007) EZ-Tax: Tax Salience and Tax Rates. NBER Working Paper 12924.

Friedman, Milton, \& Rose Friedman (1998) Two Lucky People: Memoirs. Chicago, IL: Univ. of Chicago Press.

Holtzblatt, Janet, \& Janet McCubbin (2004) "Issues Affecting Low-Income Filers," in H. Aaron \& J. Slemrod, eds., The Crisis in Tax Administration. Washington, DC: Brookings Institution.

Kish, Leslie (1949) "A Procedure for Objective Respondent Selection with the Household," $44 \mathrm{~J}$. of the American Statistical Association 380.

Kopczuk, Woijczek, \& Christian Pop-Eleches (2007) "Electronic Filing, Tax Preparers, and Participation in the Earned Income Tax Credit," 91 (7-8) J. of Public Economics 1351-1367.

President's Advisory Panel on Federal Tax Reform (2005) Simple, Fair, and Pro-Growth: Proposals to Fix America's Tax System. Washington, DC: President's Advisory Panel on Federal Tax Reform.

Rhine, Sherrie (2005) The Eamed Income Tax Credit Program: Using the EITC as a Tool for Banking, the Unbanked and Promoting Saving. New York: Federal Reserve Bank of New York.

Shapiro, Matthew, \& Joel Slemrod (1995) "Consumer Response to the Timing of Income: Evidence from a Change in Tax Withholding," 85 American Economic Rev. 274.

Souleles, Nicholas (1999) "The Response of Household Consumption to Income Tax Refunds," 89 American Economic Rev. 947. 
Thaler, Richard (1990) “Anomalies: Saving, Fungibility, and Mental Accounts," 4 J. of Economic Perspectives 193.

Thaler, Richard, \& George Loewenstein (1989) "Intertemporal Choice," 3 J. of Economic Perspectives 181.

Tufano, Peter, Daniel Schneider, \& Sondra Beverly (2005) Leveraging Tax Refunds to Encourage Savings. Retirement Security Project Policy Brief. 